\title{
PEMBERDAYAAN MASYARAKAT MISKIN \\ DI DESA GUNUNGCUPU KECAMATAN SINDANGKASIH \\ MELALUI PENYULUHAN TENTANG ARTI PENTING PENDIDIKAN UNTUK MENINGKATKAN INDEKS PEMBANGUNAN MANUSIA
}

\author{
Yeni Wijayanti*, Sri Pajriah, Yadi Kusmayadi \\ Fakultas Keguruan dan Ilmu Pendidikan Universitas Galuh \\ *Email: yeniunigal@gmail.com \\ (Diterima 03-03-2020; Disetujui 24-03-2020)
}

\begin{abstract}
ABSTRAK
Pendidikan menjadi salah satu tolok ukur Indeks Pembangunan Manusia. Oleh karena itu, penting kiranya untuk meningkatkan pemahaman bagi masyarakat tentang pentingnya pendidikan yang berpengaruh terhadap kualitas manusia. Sasaran yang dituju dalam pengabdian ini adalah masyarakat miskin yang memiliki pemahaman kurang terhadap pentingnya pendidikan. Tujuan kegiatan ini adalah agar kualitas sumber daya manusia Desa Gunungcupu dapat meningkat, mengingat jumlah penduduknya yang besar. Metode yang digunakan untuk mewujudkan pemberdayaan masyarakat dalam bidang pendidikan tersebut adalah dengan metode penyuluhan yang disampaikan secara lisan. Hasil umum yang diharapkan dapat tercapai adalah adanya perubahan pola pikir, sikap, dan perilaku, dan secara khusus adalah meningkatnya pemahaman masyarakat terutama masyarakat miskin mengenai pendidikan yang mempunyai arti penting terhadap Indeks Pembangunan Manusia.
\end{abstract}

Kata Kunci: Pemberdayaan, Pendidikan, Indeks Pembangunan Manusia

ABSTRACT

Education is one of the benchmarks of the Human Development Index. Therefore, it is important to increase understanding for the community about the importance of education that affects human quality. The target in this service is the poor who have less understanding of the importance of education. The purpose of this activity is to improve the quality of human resources in Gunungcupu Village, given the large population. The method used to realize community empowerment in the field of education is the counseling method that is delivered orally. The general outcome that is expected to be achieved is a change in mindset, attitudes, and behavior, and in particular is an increase in public understanding, especially of the poor about education, which has an important meaning on the Human Development Index.

Keywords: Empowerment, Education, Human Development Index

\section{PENDAHULUAN}

Pendidikan salah satu penentu Indeks Pembangunan Manusia (IPM) yang dikembangkan oleh United Nation Development Program (UNDP). Aspek pendidikan diukur dengan dua indikator, yaitu angka melek huruf (AMH) penduduk 15 tahun ke atas dan rata-rata lama sekolah (RLS). Pendidikan tidak semata diidentikkan dengan pendidikan formal yang mengharuskan peserta didik harus mengikuti proses belajar mengajar di sebuah tempat formal. Lebih dari itu, konteks pendidikan sangatlah luas. Terlepas dari itu, pemerintah dan lembaga pendidikan harus fokus untuk meningkatkan kualitas pendidikannya (Nugrahadi, 2017).

Kesejahteraan dapat dilihat seberapa banyak/tinggi angka kemiskinan. Sedangkan kemiskinan dapat disebabkan karena sumber daya manusia tidak berkualitas, yang tentunya diakibatkan oleh rendahnya mutu pendidkan yang diperoleh. Oleh karena itu, pendidikan merupakan elemen penting pembangunan dan perkembangan sosial ekonomi masyarakat. 
Pemberdayaan Masyarakat Miskin di Desa Gunungcupu Kecamatan Sindangkasih Melalui Penyuluhan Tentang Arti Penting Pendidikan Untuk Meningkatkan Indeks Pembangunan Manusia

Yeni Wijayanti, Sri Pajriah, Yadi Kusmayadi

Tanpa disadari bersama, pendidikan memiliki arti penting bagi upaya meningkatkan kualitas hidup individu, masyarakat, dan bangsa. Proses pendidikan yang baik sesungguhnya adalah upaya sadar individu atau masyarakat untuk meningkatkan pengetahuan, ketrampilan, serta memperluas wawasannya. Berbekal pendidikan yang cukup, setiap individu dituntut dengan kemampuannnya sendiri untuk dapat meningkatkan partisipasinya dalam berbagai aspek kehidupan, sehingga dapat hidup secara lebih layak.

Dalam perspektif makro, ukuran yang sangat mendasar dari tingkat pendidikan adalah angka melek huruf penduduk dewasa (usia 15 tahun ke atas). Secara konsepsi, angka melek huruf menunjukkan kemampuan individu yang bisa membaca dan menulis huruf latin dan lainnya. Besaran angkanya dapat menggambarkan bagaimana mutu/kualitas sumber daya manusia dan digunakan pula dalam membandingkan kesempatan dan kualitas pendidikan antar wilayah.

Permasalahan yang dihadapi didunia pendidikan adalah kualitas dan akses. Rendahnya kualitas pendidikan di antara penyebabnya adalah tidak meratanya penyebaran guru dan rendahnya mutu guru. Penumpukkan guru-guru di kota-kota besar tak bias ditampik. Sementara di daerah terpencil atau pelosok, guru masih kurang dan kualitasnya juga rendah.

Terbatasnya anggaran pendidikan dari pemerintah seringkali menjadi dilema, target pencapaian rata-rata lama sekolah penduduk harus menghadapi kenyataan bahwa tidak semua rumah tangga mampu menyekolahkan anak-anaknya hingga pendidikan tinggi. Semakin mahalnya biaya sekolah menyebabkan sebagaian orang tua terpaksa memutuskan kelangsungan sekolah anak-anaknya dan diarahkan membantu ekonomi keluarga.

Di sisi lain, pendidikan berperan penting dalam meningkatkan kesejahteraan dalam hal ini IPM karena pembangunan manusia yang baik akan menjadikan faktor-faktor produksi ekonomi yang ada sehingga akan meningkatkan daya beli. Pembangunan manusia dengan pendidikan juga akan meningkatkan rata-rata lama sekolah dan mendongkrak angka melek huruf. Dan dengan ditunjang pendidikan, angka harapan hidup dapat naik karena pola hidup sehat yang dijalankan akibat wawasan kesehatan yang diperoleh dengan pendidikan.

Menurut Biro Pusat Statistik, IPM mengukur capaian pembangunan manusia berbasis sejumlah komponen dasar kualitas hidup. Sebagai ukuran kualitas hidup, IPM dibangun melalui pendekatan tiga dimensi dasar, yaitu umur panjang dan sehat, pengetahuan, dan kehidupan yang layak. Ketiga dimensi tersebut memiliki pengertian sangat luas karena terkait banyak faktor. Untuk mengukur dimensi kesehatan, digunakan angka harapan hidup waktu lahir. Selanjutnya untuk mengukur dimensi pengetahuan digunakan gabungan indikator angka melek huruf dan rata-rata lama sekolah. Adapun untuk mengukur dimensi hidup layak digunakan indikator 
kemampuan daya beli masyarakat terhadap sejumlah kebutuhan pokok yang dilihat dari ratarata besarnya pengeluaran per kapita sebagai pendekatan pendapatan yang mewakili capaian pembangunan untuk hidup layak.

Lebih lengkapnya, komponen Indeks Pembangunan Manusia meliputi.

a. Angka Harapan Hidup

Angka Harapan Hidup (AHH) pada waktu lahir merupakan rata-rata perkiraan banyak tahun yang dapat ditempuh oleh seseorang selama hidup.

b. Angka Melek Huruf

Angka melek huruf adalah persentase penduduk usia 15 tahun ke atas yang dapat membaca dan menulis huruf latin dan atau huruf lainnya.

c. Rata-rata Lama Sekolah

Rata-rata lama sekolah menggambarkan jumlah tahun yang digunakan oleh penduduk usia 15 tahun ke atas dalam menjalani pendidikan formal.

d. Pengeluaran Riil per Kapita yang disesuaikan

UNDP mengukur standar hidup layak menggunakan Produk Domestik Bruto (PDB) riil yang disesuaikan, sedangkan BPS dalam menghitung standar hidup layak menggunakan rata-rata pengeluaran per kapita riil yang disesuaikan dengan formula Atkinson.

Rendahnya mutu pendidikan menimbulkan rendahnya pula kualitas sumber daya manusia masyarakat miskin Desa Gunungcupu yang mencakup berbagai dimensi diantaranya adalah dimensi politik, sosial, lingkungan, ekonomi, dan aset. Dalam dimensi politik, tidak adanya wadah/organisasi yang memperjuangkan aspirasi dan kebutuhan warga miskin, sehingga mereka benar-benar tersingkir dari proses pengambilan keputusan penting yang menyangkut diri mereka. Akibatnya, mereka juga tidak memiliki akses yang memadai ke berbagai sumber daya kunci yang dibutuhkan untuk menyelenggarakan hidup mereka secara layak termasuk akses informasi. Bila dilihat dari organisasi yang ada di desa, jelas bahwa tidak ada lembaga yang mewadahi masyarakat miskin. Lembaga-lembaga seperti LKMD, karang taruna, BPD, dan yang lainnya biasanya beranggotakan tokoh-tokoh masyarakat, atau tokoh-tokoh pemuda. Bagi masyarakat miskin ada perasaan tidak memiliki yang menyebabkan mereka enggan masuk ke dalam organisasi tersebut, padahal itu diperuntukkan untuk semua warga.

Dimensi selanjutnya adalah dimensi sosial, di mana warga miskin tidak terintegrasikan dalam institusi sosial yang ada, terinternalisasikannnya budaya kemiskinan yang merusak kualitas manusia dan etos kerja mereka, serta pudarnya nilai-nilai kapital sosial. Permasalahan ini hampir sama dengan dimensi politik, hanya institusi yang membedakanya. Tetapi pola 
Pemberdayaan Masyarakat Miskin di Desa Gunungcupu Kecamatan Sindangkasih Melalui Penyuluhan Tentang Arti Penting Pendidikan Untuk Meningkatkan Indeks Pembangunan Manusia

Yeni Wijayanti, Sri Pajriah, Yadi Kusmayadi

pandang masyarakat terhadap institusi sosial cenderung sama terhadap organisasi politik atau yang lainnya.

Dimensi yang ketiga adalah dimensi lingkungan, yaitu sering menunjukkan perilaku dan cara pandang yang tidak berorientasi pada pembangunan berkelanjutan, sehingga cenderung memutuskan dan melaksanakan kegiatan-kegiatan yang kurang menjaga kebersihan, kelestarian dan perlindungan lingkungan serta pemukiman.

Dimensi yang keempat adalah dimensi ekonomi, terlihat dari rendahnya penghasilan sehingga tidak mampu untuk memenuhi kebutuhan hidup mereka sampai batas yang layak. Penghasilan masyarakat miskin Desa Karanganyar terbatas hanya untuk kebutuhan pangan saja, yang terkadang makan sehari dua kali saja. Sehingga kebutuhan untuk yang lainnya seperti pendidikan, kesehatan, dan sandang tidak terpenuhi. Mereka juga sering terjerat hutang dengan rentenir, karena cara mudah mendapat pinjaman tanpa banyak persyaratan. Kadang mereka mengabaikan bunga yang tinggi dari para rentenir demi untuk mendapatkan pinjaman yang cepat dan mudah. Sama sekali mereka tidak tertarik dengan bank atau sejenisnya yang lebih menawarkan bunga lebih rendah. Selain itu, pengelolaan ekonomi rumah tangga sering dicampuradukkan bagi yang mempunyai usaha sampingan. Pemasukan dari usaha sering digunakan untuk keperluan sehari-hari, bukan untuk menjalankan roda usaha mereka.

Dimensi yang terakhir adalah dimensi aset, hal ini ditandai dengan rendahnya tingkat kepemilikan masyarakat miskin dalam berbagai hal yang mampu menjadi modal hidup mereka, termasuk aset kualitas sumber daya manusia, peralatan kerja, modal dana, hunian, dan sebagainya.

Pendidikan secara umum mempunyai arti suatu proses kehidupan dalam mengembangkan diri tiap individu untuk dapat melangsungkan kehidupan. Pendidikan dianggap penting karena dapat menjadi bekal untuk memperoleh pekerjaan yang layak. Padahal tujuan pendidikan tidak seperti itu, pendidikan penting karena ingin memanusiakan manusia sesuai dengan teori pendidikan. Sehingga menjadi seorang yang terdidik itu sangat penting. Pendidikan pertama kali yang kita dapatkan di lingkungan keluarga, lingkungan sekolah dan lingkungan masyarakat.

Di Desa Gunungcupu banyak orang tua yang tidak dapat menyekolahkan anak-anaknya sampai pendidikan tinggi. Rendahnya mutu pendidikan di Desa Gunungcupu mempengaruhi kehidupan masyarakat miskin, seperti terlihat dari segi politik, sosial, lingkungan, ekonomi, dan aset.

Rasionalisasi kegiatan pengabdian mencakup pemberian informasi dan pemahaman pada masyarakat miskin tentang wajib belajar dan arti pentingnya pendidikan untuk meningkatkan 
IPM. Tujuan yang dicapai dalam pengabdian ini adalah meningkatkan pemahaman masyarakat miskin di Desa Gunungcupu tentang arti penting pendidikan bagi peningkatan Indeks Pembangunan Manusia.

Berdasarkan latar belakang di atas, maka penulis bermaksud melakukan pengabdian berjudul "Pemberdayaan Masyarakat Miskin Di Desa Gunungcupu Kecamatan Sindangkasih Melalui Penyuluhan Tentang Arti Penting Pendidikan Untuk Meningkatkan Indeks Pembangunan Manusia”.

\section{BAHAN DAN METODE}

Khalayak sasaran dari penyuluhan pendidikan ini adalah masyarakat miskin Desa Gunungcupu Kecamatan Sindangkasih, yang diharapkan setelah mendapatkan pemahaman tentang arti penting pendidikan akan dapat memotivasi mereka dalam meningkatkan kualitas hidup mereka. Kegiatan pengabdian dilakukan di Aula kantor Desa Gunungcupu. Metode yang digunakan dalam kegiatan pengabdian ini adalah dengan penyuluhan dalam bentuk ceramah, tanya jawab dan diskusi.

\section{HASIL DAN PEMBAHASAN}

Secara geografis, Desa Gunungcupu berada pada $450 \mathrm{~m}$ dpl. Desa Gunungcupu terdiri atas 10 dusun, antara lain dusun Desakidul, Desakaler, Gandasari, Gunungrasa, Cidolog, Bojonggaok, Lenggorsari, Kadupugur, Sirnagalih, dan Subang. Jumlah penduduk Desa Gunungcupu 8.897 jiwa yang terdiri atas 2.390 kepala keluarga dengan rincian jumlah penduduk laki-laki sebanyak 4.651 jiwa dan perempuan 4.246 jiwa. Mata pencaharian masyarakat Desa Gunungcupu mayoritas adalah bertani, baik itu petani maupun buruh tani. data kependudukan menurut tingkat pendidikan dapat digambarkan sebagai berikut, lulusan SD sebanyak 2.286, lulus SMP 1.027, lulus SMA 349, lulus akademi 54, dan lulus sarjana 43 orang.

Sementara itu, Pemerintah Desa Gunungcupu memiliki program pembangunan yang meliputi:

1. Pemberdayaan Masyarakat Desa

Pemberdayaan masyarakat dimaksudkan sebagai suatu upaya untuk mengkondisikan masyarakat terutama lapisan yang saat ini kurang berkesempatan dalam kiprah pembangunan baik sebagai pelaku maupun penerima manfaat melalui suatu perlakuan tertentu seperti peningkatan kesempatan kerja, pembinaan dan penciptaan kesempatan berusaha dengan harapan bisa hidup mandiri dan memadai.

Prioritas kegiatan dalam pemberdayaan masyarakat antara lain: 
Pemberdayaan Masyarakat Miskin di Desa Gunungcupu Kecamatan Sindangkasih Melalui Penyuluhan Tentang Arti Penting Pendidikan Untuk Meningkatkan Indeks Pembangunan Manusia

Yeni Wijayanti, Sri Pajriah, Yadi Kusmayadi
a. Pengembangan kewirausahaan (seperti industri rumah tangga, dll.).
b. Pencipataan lapangan kerja (seperti proyek umum, padat karya, dll.).
c. Pembinaan dan peningkatan keterampilan.
d. Mengusahakan adanya bantuan permodalan khusus bagi masyarakat yang memenuhi persyaratan (baik dari pemerintah maupun kemitraan).

2. Peningkatan Pemanfaatan Potensi Desa

Desa Gunungcupu yang memiliki sumber daya alam yang potensial terutama bagi pengembangan pertanian tanaman pangan, peternakan, perikanan, yang berwawasan agribisnis. Upaya dalam optimalisasi pemanfaatan potensi desa tersebut dilakukan tanpa mengabaikan aspek kelestarian lingkungan hidup, kesehatan dan tata ruang dengan harapan pembangunan yang dilakukan dapat berkesinambungan serta memberikan manfaat yang besar bagi masyarakat.
a. Pertanian tanaman pangan, peternakan dan perikanan air tawar (kolam).
b.Peningkatan keterampilan/pengetahuan petani.
c. Pembinaan penerapan teknologi budidaya, pegolahan dan pemasaran.

\section{Penyediaan Sarana}

Keberadaan prasarana sebagai pendukung lancarnya pembangunan, harus tercukupi dan memadai sehingga dapat mendorong pada aktivitas ekonomi dan sosial masyarakat sejalan dengan makin berkembangnya tuntutan dan kebutuhan serta dinamika kehidupan masyarakat.

Dalam hal penyediaan prasarana diprioritaskan pada:

a. Peningkatan kualiltas fisik jalan desa dan jalan gang dusun.

b.Peningkatan efektifitas saluran-saluran air baik irigasi maupun pedesaan.

c. Peningkatan kualitas fisik bangunan-bangunan umum dan peribadatan.

4. Peningkatan Pendapatan Asli Desa

Peningkatan Pendapatan Asli Desa pada intinya adalah meningkatkan peran keuangan desa dari pendapatan asli desa terhadap anggaran pendapatan dan belanja desa. Dalam kontek ini, peningkatan peran tidak saja hanya menggambarkan mengenai besaran penerimaan tetapi juga besaran proporsinya terhadap anggaran itu sendiri sehingga dalam jangka panjang akan nampak kemandirian desa dilihat dari sisi pembiayaan.

Langkah-langkah upaya peningkatan Pendapatan Asli Desa adalah:

a. Intesifikasi pungutan Urunan Desa serta sumber pendapatan lain yang sah seperti melalui pembinaan, peningkatan intensitas penagihan, penyesuaian tarif melalui keputusan bersama dangan Badan Musyawarah Desa (BPD). 
b. Ektensifikasi yaitu memperluas/menggali sumber-sumber pendapatan lainnya.

\section{Peningkatan Nilai-nilai Budaya dan Agama}

Upaya dalam hal peningkatan nilai-nilai budaya/keagamaan dimaksud adalah peningkatan efektifitas keberadaan dan kegunaanya sehingga manfaatnya lebih dibutuhkan/dirasakan oleh masyarakat (seperti kelompok jimpitan beras, kematian, keamanan, kelompok pengajian orang tua dan atau remaja, simpan pinjam dan kegiatan gotong royong lainnya yang telah ada dan berkembang di tiap dusun )

Dalam hal kebijakan di bidang agama adalah menempatkan fungsi dan kedudukan agama sebagai pola hidup dan kehidupan dalam penyelenggaraan pemerintahan desa, bermasyarakat, berbangsa dan bernegara, meningkatkan kerukunan, meningkatkan kualitas sumber daya manusia pendidik dan sarana prasarana keagamaan dalam menjalankan ibadahnya dengan penuh ketenangan dan ketentraman.

6. Sumber Daya Alam, Lingkungan Hidup dan Tata Ruang

Pembangunan sumber daya alam dan lingkungan hidup diarahkan dalam rangka pemanfaatan/pengelolaanya agar sesuai dengan daya dukungnya untuk kesejahteraan masyarakat dengan memperhatikan kaidah konservasi dan kelestariannya, merehabilitasi sumber daya alam yang rusak, sehingga dapat memberikan manfaat yang optimal bagi peningkatan kesejahteraan masyarakat dan fungsi keseimbangan lingkungan hidup.

Dalam hal kebijakan tata ruang diarahkan untuk pemanfaatan ruang sesuai dengan fungsinya dengan tidak mengabaikan aspek kesehatan, kebersihan, keindahan dan ketertiban.

7. Keamanan dan Ketertiban

Arah kebijakan pembangunan di bidang keamanan dan ketertiban desa untuk mewujudkan kehidupan yang tenteram dan tertib dengan upaya antara lain:

a. Peningkatan nilai sadar hukum masyarakat melalui penyuluhan dan pembinaan tentang hukum kepada seluruh lapisan masyarakat.

b. Mengitensifkan pertahanan dan keamanan dengan memfungsikan sistim keamanan lingkungan (Siskamling), pembinaan pertahanan sipil dan perlindungan masyarakat.

8. Penyelenggaraan Pemerintah Desa

Pembangunan di bidang penyelenggaraan pemerintahan desa diarahkan pada:

a. Penyempurnaan sarana dan prasarana kantor desa dan balai desa guna ketertiban kantor dan kelancaran pemerintahan sehingga dapat meningkatkan pelayanan yang baik kepada masyarakat. 
Pemberdayaan Masyarakat Miskin di Desa Gunungcupu Kecamatan Sindangkasih Melalui Penyuluhan Tentang Arti Penting Pendidikan Untuk Meningkatkan Indeks Pembangunan Manusia

Yeni Wijayanti, Sri Pajriah, Yadi Kusmayadi

b. Meningkatkan manajemen pemerintahan desa melalui peningkatan kinerja pemerintahan untuk mewujudkan pemerintahan yang bersih, kuat, berdaya saing dan berjiwa wirausaha.

Menyusun rencana pembangunan bukanlah suatu hal yang mudah sebagaimana yang diharapkan jika tidak didukung oleh data dan informasi yang sahih dan terpercaya. Perencanaan yang baik harus memenuhi persyaratan minimal antara lain data yang lengkap dan benar, mengetahui objek yang akan dibangun, rencana mudah dipahami dan dapat dilaksanakan, bersifat pemecahan masalah dan bermakna menyusun rencana pembangunan. Dalam bidang pembangunan desa dan pembangunan masyarakat pedesaan, persyaratan minimal tersebut diatas adalah mutlak diperlukan.

Program yang dicanangkan tersebut di atas secara eksplisit menggambarkan upaya peningkatan kondisi bagi masyarakat Desa Gunungcupu, namun memiliki kekurangan yang kurang dapat memotivasi masyarakatnya untuk meningkatkan pendidikan. Hal-hal yang terkait dengan pemberdayaan yang sifatnya non materiil masih minim. Apalagi jika dilihat dari data kependudukan yang menunjukkan taraf pendidikannya masih kurang. Oleh karena itu, perlu kiranya dilakukan dorongan dengan melakukan pengabdian yang berbentuk penyuluhan.

Langkah awal kegiatan pengabdian adalah observasi yang dilanjutkan dengan mengidentifikasi masalah. Khalayak sasaran seperti yang telah disebutkan di atas adalah masyarakat miskin/pra sejahtera. Setelah itu, kemudian disusun rumusan masalah beserta kerangka pemecahan masalahnya.

Sebelum melaksanakan kegiatan penyuluhan, terlebih dahulu dilakukan persiapanpersiapan seperti mencari studi pustaka/literatur tentang pemberdayaan, arti penting pendidikan dan IPM. Setelah itu menyiapkan materi tentang arti penting pendidikan untuk meningkatkan IPM. Tempat yang dipilih untuk mengadakan penyuluhan adalah aula kantor Desa Gunungcupu.

Hasil yang ideal dari sebuah program tentunya mencakup unsur fisik dan nonfisik. Begitu pula dengan program yang dijalankan oleh pemerintah desa. Akan tetapi, terkadang kebijakankebijakan tersebut tidak menyentuh lapisan masyarakat yang paling bawah. Oleh karena itu, diperlukan upaya-upaya yang dilakukan baik dari kalangan intern desa maupun ekstern desa untuk sampai pada lapisan masyarakat yang paling bawah.

Pemberdayaan yang dilakukan dalam bentuk penyuluhan ini merupakan bagian dari upaya pembangunan nonfisik, karena yang diharapkan setelah khalayak sasaran menerima pemahaman maka akan terjadi perubahan dalam pola pikir dan sikap/perilaku sesuai dengan yang diharapkan dalam penyuluhan ini. Pola pikir yang diharapkan berubah setelah menerima 
penyuluhan ini adalah masyarakat miskin tidak lagi memandang bahwa pendidikan adalah hal yang harus mengeluarkan biaya tinggi; tidak lagi mempunyai rasa takut untuk menyekolahkan anak atau anggota keluarganya ke jenjang pendidikan yang lebih tinggi; dan perilaku yang diharapkan adalah mereka menyekolahkan anak atau anggota keluarganya ke jenjang pendidikan yang lebih tinggi. Pendidikan memiliki peranan pendting dalam kehidupan manusia. Pendidikan dapat membentuk kepribadian manusia dan juga menentukan produktivitas dan prestasi.

Beberapa faktor yang menyebabkan perlunya mengembangkan pendidikan adalah pendidikan lebih tinggi memperluas pengetahuan masyarakat dan mempertinggi rasionalitas mereka; pendidikan memungkinkan masyarakat mempelajari pengetahuan teknis yang dibutuhkan; dan pengetahuan yang didapat dari pendidikan menjadi pendorong terciptanya pembaruan di berbagai bidang. Dengan demikian, tingkat pendidikan yang semakin meningkat akan dapat menjamin pembaruan dalam berbagai hal yang terus berlangsung.

\section{KESIMPULAN DAN SARAN}

\section{Kesimpulan}

Hasil yang diperoleh dari kegiatan pemberdayaan masyarakat miskin di Desa Gunungcupu Kecamatan Sindangkasih Kabupaten Ciamis melalui penyuluhan mengenai arti penting pendidikan untuk meningkatkan IPM adalah antusiasme masyarakat yang meningkat mendengarkan paparan dan bertambahnya pemahaman tentang arti pendidikan bagi kehidupan mereka.

\section{Saran}

Berdasarkan hasil kegiatan pengabdian yang telah dilaksanakan, perlu adanya kesinambungan program dan monitoring pasca pengabdian ini agar tujuan yang diharapkan dapat tercapai secara maksimal.

\section{DAFTAR PUSTAKA}

Atmanti, H.D. 2005. Investasi Sumber Daya Manusia Melalui Pendidikan. Jurnal Dinamika Pembangunan, 2(1): 30-39.

http://www.bps.go.id

Nugrahadi, E,W. dan Rinaldi, M. 2017. Pendidikan sebagai Pendorong Peningkatan Indeks Pembangunan Manusia di Indonesia. Jurnal Mediasi, 06(2): 34-43.

Poedjiadi, A. 1997. Perkembangan Ilmu (Sains) Pendidikan untuk Peningkatan Wawasan Keilmuan dan Teknologi di Indonesia. Makalah disampaikan pada Konvensi Internasional Ilmu Pendidikan. Soul - Korea 26 - 30 Mei 1997. 
Pemberdayaan Masyarakat Miskin di Desa Gunungcupu Kecamatan Sindangkasih Melalui Penyuluhan Tentang Arti Penting Pendidikan Untuk Meningkatkan Indeks Pembangunan Manusia

Yeni Wijayanti, Sri Pajriah, Yadi Kusmayadi

\section{Profil Desa Gunungcupu}

Siregar, N.S.S. 2013. Pesepsi Orang Tua terhadap Pentingnya Pendidikan Bagi Anak. Jurnal Ilmu Pemerintahan dan Sosial Politik, 1(1): 11-27.

Sutrisnowati, Sri Agustin, dkk. 2012. Pelatihan Pembuatan Media Kreatif Sederhana sebagai Pendukung Pembelajaran Geografi untuk Guru-Guru SMA/MA Se-Kabupaten Gunung Kidul. Laporan PPM. UNY: FIS. 